\title{
Review \\ Does ENaC Work as Sodium Taste Receptor in Humans?
}

\author{
Albertino Bigiani iD \\ Dipartimento di Scienze Biomediche, Metaboliche e Neuroscienze, Università di Modena e Reggio Emilia, \\ 41125 Modena, Italy; albertino.bigiani@unimore.it; Tel.: +39-059-205-5349
}

Received: 29 March 2020; Accepted: 21 April 2020; Published: 24 April 2020

\begin{abstract}
Taste reception is fundamental for the proper selection of food and beverages. Among the several chemicals recognized by the human taste system, sodium ions $\left(\mathrm{Na}^{+}\right)$are of particular relevance. $\mathrm{Na}^{+}$represents the main extracellular cation and is a key factor in many physiological processes. $\mathrm{Na}^{+}$elicits a specific sensation, called salty taste, and low-medium concentrations of table salt $(\mathrm{NaCl}$, the common sodium-containing chemical we use to season foods) are perceived as pleasant and appetitive. How we detect this cation in foodstuffs is scarcely understood. In animal models, such as the mouse and the rat, the epithelial sodium channel $(\mathrm{ENaC})$ has been proposed as a key protein for recognizing $\mathrm{Na}^{+}$and for mediating preference responses to low-medium salt concentrations. Here, I will review our current understanding regarding the possible involvement of $\mathrm{ENaC}$ in the detection of food $\mathrm{Na}^{+}$by the human taste system.
\end{abstract}

Keywords: sodium taste; sodium receptor; salt taste; amiloride; taste transduction

\section{Introduction}

The sodium ion $\left(\mathrm{Na}^{+}\right)$is an essential mineral for our body because it regulates the osmolality of the extracellular fluid and plays a key role in many physiological processes, from the generation of nerve impulses to renal function. $\mathrm{Na}^{+}$is lost continuously through urine, feces, and sweat. Thus, to maintain proper bodily balance, we need to replace losses by the ingestion of food containing this cation. Our ability to detect $\mathrm{Na}^{+}$in foodstuffs relies on the taste system: $\mathrm{Na}^{+}$elicits a specific sensation called salty taste [1,2] that guides the intake of this important mineral [3,4]. Table salt $(\mathrm{NaCl})$ represents a prototypic chemical substance evoking salty taste. It is well established that $\mathrm{Na}^{+}$is responsible for the perceived saltiness and for the pleasantness of low to medium concentrations of table salt $[4,5]$.

The early events in taste reception typically include the interaction of the chemical stimulus with a membrane receptor in taste cells, specialized epithelial cells clustered in sensory end-organs called taste buds [6]. Most of studies on sodium taste reception have been performed on laboratory rodents (mouse and rat). In these mammals, the epithelial sodium channel (ENaC) works as low-salt receptor, mediating acceptance responses to low-medium salt concentrations and driving salt consumption [5]. The obvious question is then: does $\mathrm{ENaC}$ play any role in sodium detection in humans? In this review, I will discuss current information supporting or arguing against the possible involvement of this ion channel in human salt taste. I will evaluate whether data from human studies fit the model for the detection of $\mathrm{Na}^{+}$based on $\mathrm{ENaC}$ as sodium receptor localized at the apical membrane of taste cells; that is, where these cells contact the saliva in the so-called taste pore region of taste buds $[6,7]$.

\section{Psychophysics}

In laboratory rodents, a pharmacological feature of taste $\mathrm{ENaC}$ is its sensitivity to amiloride, a diuretic drug, which selectively blocks the channel at submicromolar concentrations [8]. Since ENaC is inhibited by amiloride, application of this drug during stimulation with $\mathrm{NaCl}$ blunts the taste 
response and the attractiveness of low sodium concentrations [9,10]. Following the same methodological approach, the involvement of the $\mathrm{ENaC}$ pathway in human taste reception has been investigated over 15 years by sensory evaluation of the amiloride effect on salt taste. Unexpectedly, findings have been very controversial. Some authors found that indeed the presence of amiloride reduced the perceived saltiness of the $\mathrm{NaCl}$ solutions, although to varying degrees [11-15]. On the contrary, other investigators found that amiloride had negligible or no effect on salt taste [16-21]. The discrepancy among studies might be due to differences in the experimental design. For example, perception arising from stimulation of the anterior tongue seems to be affected by amiloride [11-13], whereas perception from whole-mouth stimulation is not [16]. This raises the possibility that in the whole-mouth protocol, additional sensory inputs from the oral cavity may "obscure" the information conveyed by amiloride-sensitive pathway at the level of central processing [22]. However, other studies in which stimuli were delivered only to the anterior dorsal surface of the tongue failed to find a significant effect of amiloride on saltiness perception $[17,20,21]$. Of note, amiloride strongly reduces the sour side taste of salt solutions when subjects can use not only one response category (saltiness), but all taste qualities (saltiness, sweetness, sourness, bitterness) to describe their perception $[17,19]$.

Further factors affecting the outcome of the sensory assays might include the impact of amiloride bitterness in establishing the taste quality of salt solutions as well as the amiloride concentration tested. It is worth noting that some studies showing the amiloride effect used high drug concentrations $(500 \mu \mathrm{M}$ and $1 \mathrm{mM}$ ) [12-14], whereas studies claiming a negligible effect of amiloride on salt perception adopted smaller concentrations of the drug $(10-100 \mu \mathrm{M})[17,18,20,21]$. The specificity of amiloride for ENaC is true only for low drug concentration (half-maximal inhibition in submicromolar range; [8]). At higher concentrations, amiloride also affects other cellular proteins, including ion channels, transporters, and receptors [3,23]. A few examples of the molecular targets other than $\mathrm{ENaC}$ are shown in Table 1. It is worth noting the same proteins are also found in the taste cells of laboratory rodents (Table 1 , rightmost column). As nicely pointed out by Lindemann [3] "if concentrations above $10 \mu \mathrm{M}$ are needed for half-maximal inhibition, effects of amiloride other than blockage of $\mathrm{Na}^{+}$channels need to be considered". Thus, it is possible that human testing may have yielded contrasting results due to nonspecific effects of amiloride. However, it is also possible that $\mathrm{ENaC}$ in humans displays a lower sensitivity to amiloride than typical $\mathrm{ENaC}$, as indicated by molecular biology studies (see below).

Table 1. Molecular targets, other than $\mathrm{ENaC}$, for the inhibitory effect of amiloride expressed by the inhibition constant $\left(K_{i}=\right.$ amiloride concentration producing $50 \%$ inhibition). Data refer to nontaste tissues. The occurrence of these molecular targets in rodents taste cells is also referenced.

\begin{tabular}{cccc}
\hline Molecular Target & $\boldsymbol{K}_{\boldsymbol{i}}(\boldsymbol{\mu M})$ & Cell/Tissue & Occurrence in Rodent Taste Cells \\
\hline T-type calcium channel & 30 & $\begin{array}{c}\text { Mouse neuroblastoma and chick } \\
\text { DRG }{ }^{1} \text { neurons [24] }\end{array}$ & {$[25,26]$} \\
\hline $\mathrm{Na}^{+} / \mathrm{H}^{+}$exchanger & 30 & $\begin{array}{c}\text { Rabbit renal microvillous } \\
\text { membrane [27] }\end{array}$ & {$[28-30]$} \\
\hline Muscarinic receptors & $40-80$ & Rabbit pancreatic acini [31] & {$[32,33]$} \\
\hline & & ${ }^{1}$ Dorsal Root Ganglion.
\end{tabular}

\section{Electrophysiology}

In laboratory animals, application of $\mathrm{NaCl}$ solution to the tongue mucosa produces a transepithelial current due to the movement of ions across the epithelium $[9,34,35]$. This current is believed to be sustained mainly by $\mathrm{Na}^{+}$entering taste cells via the apical $\mathrm{ENaC}$ since amiloride strongly reduces it. Obviously, during $\mathrm{NaCl}$ stimulation, a voltage drop between mucosal and serosal side of the tongue develops, and this voltage drop can be measured with adequate instrumentation $[9,34,35]$. This approach has been applied to human volunteers to evaluate the contribution of the amiloride-sensitive pathway to the perceived saltiness. Electrophysiological recordings of lingual surface potential (LSP) in response to focal $\mathrm{NaCl}$ stimulation have provided evidence that, in some individuals, amiloride (100 
$\mu \mathrm{M})$ was able to reduce the voltage drop caused by $\mathrm{NaCl}$ application [36]. However, the effect was highly variable among individuals, ranging from $0 \%$ to $42 \%$ inhibition. Further studies demonstrated a positive correlation between LSP and the perceived intensity of saltiness [37]. It was also found that in expert salt tasters, amiloride $(10 \mu \mathrm{M})$ impaired the ability to distinguish between two different salt concentrations (100 and $300 \mathrm{mM} \mathrm{NaCl}$ ) [37]. Again, not all subjects exhibiting a LSP during $\mathrm{NaCl}$ stimulation were sensitive to amiloride, underscoring the high variability of the amiloride effect across individuals observed previously [36]. Nonetheless, these electrophysiological studies seem to confirm the psychophysical findings suggesting suppression of perceived saltiness by amiloride in some individuals when a small area of the tongue surface is stimulated [11-13].

\section{Molecular Biology and Immunohistochemistry}

In laboratory rodents, $\mathrm{ENaC}$ is an oligomeric protein made of three nonidentical subunits, named $\alpha-, \beta-$, and $\gamma$-ENaC $[38,39]$. Expression cloning studies with Xenopus oocytes have clearly indicated that the $\alpha$-subunit is required to induce channel activity, whereas the presence of the $\beta$ - and $\gamma$-subunit allows maximal expression of sodium current [40]. Although it is still unknown how these subunits assemble to form $\mathrm{ENaC}$ in taste cells [41], all of them have been detected in taste tissues from laboratory animals by using molecular and immunohistochemical techniques [42-46]. It is important to underscore that there is also direct evidence that amiloride-sensitive taste cells do have $\mathrm{ENaC}$ subunits, whereas amiloride-insensitive cells do not [46]. By applying the same techniques on tissue samples from human subjects, it has been possible to establish that $\alpha-, \beta-$, and $\gamma$-ENaCs occur in human taste papillae $[47,48]$. In man, however, taste tissues also express an additional $\delta$-subunit, which is missing in rodents $[48,49]$. The $\delta$-subunit is analog to the $\alpha$-subunit in that its presence is necessary to form a $\mathrm{Na}^{+}$-permeable channel [50]. It is then possible that in human taste tissues, $\mathrm{ENaC}$ may include either an $\alpha$ - or $\delta$-subunit. This subunit change may have an impact on the amiloride sensitivity, since replacement of $\alpha$-subunit by a $\delta$-subunit makes the channel 50-fold less sensitive to amiloride [50-52]. If this is the case, then the negligible effect of amiloride observed in some psychophysical studies (e.g., $[17,18])$ could be attributed to variations in the molecular composition of the ENaC protein [53]. It is worth noting that the expression level of $\mathrm{ENaC}$ subunits may vary significantly among subjects and that $\mathrm{ENaC} \mathrm{mRNAs}$ are also detected in nontaste epithelium [48].

The detection of $\mathrm{ENaC}$ subunits in human taste tissues does not necessarily imply that this channel is involved in the initial events of sodium detection. According to the model of sodium taste detection proposed for rodents, $\mathrm{ENaC}$ should be found at the apical membrane of taste cells to work as a sodium receptor $[3,8]$. Immunohistochemical localization of $\mathrm{ENaC}$ subunits in human lingual epithelium has revealed that $\delta$-ENaC is exclusively restricted to the taste pore region in both fungiform and circumvallate taste buds [48]. However, it has not been possible to establish whether this subunit localized to the apical membrane of taste cells or to tight junctions surrounding the apical ends of these cells. Unexpectedly, the other ENaC-subunits were found in the basolateral compartment of taste cells, which is involved in later stages of the sensory transduction and in intercellular communications with nerve endings and adjacent cells [5]. This raises the possibility that $\mathrm{ENaC}$ may serve other functions in taste buds. Recent findings indicate that $\mathrm{ENaC}$ plays a key role in the regulation of adult neurogenesis [54]. It is then tempting to speculate that $\mathrm{ENaC}$ might be involved in taste cell development since these cells continuously turnover $[55,56]$. Of note, another study found that $\delta$-ENaC immunoreactivity was distributed over both the apical and basolateral ends of fungiform taste cells [49]. Although it is not clear how to reconcile these conflicting results on labeling pattern, both findings support the notion that $\delta$-ENaC is expressed in human taste buds.

Although the model of sodium detection involving apically located $\mathrm{ENaC}$ explains several experimental observations, ENaC-subunits localized to the basolateral membrane could also mediate sodium reception by sensing $\mathrm{Na}^{+}$leaked through tight junctions around taste cells [5]. Thus, this paracellular pathway could be responsible for activation of taste cells even in the absence of apical ENaC. Since the basolateral compartment of taste cells is exposed to an extracellular solution 
containing about $150 \mathrm{mM} \mathrm{Na}^{+}$, a significant diffusion of this cation through tight junctions could occur only if $\mathrm{Na}^{+}$concentration in the mucosal surface is much higher than $150 \mathrm{mM}$. It is then possible that basolateral $\mathrm{ENaCs}$ may be relevant for sodium detection when salt concentration in the stimulating solution exceeds plasma tonicity. The basolateral localization of ENaC subunits may be a further factor in determining the variable amiloride sensitivity observed in human studies (see above).

\section{Genetics}

Single nucleotide polymorphisms (SNPs) in the gene coding for the ENaC $\beta$-subunit (SCNN1B) are somehow associated with changes in suprathreshold taste sensitivity for $\mathrm{NaCl}$ solutions, but not with salt taste threshold [57]. The $\beta$-subunit does not play a role in pore formation of the channel protein, but it is assumed to modulate channel activity and to be important for channel trafficking to the cell membrane $[40,58,59]$. Thus, these findings indicate that variations in the $\beta$-ENaC genes may contribute to differences in salt taste perception among individuals through a possible effect on the expression of $\mathrm{ENaC}$ in the taste cell membrane. Interestingly, these data imply that $\mathrm{ENaC}$ may be involved in the recognition of $\mathrm{NaCl}$ at concentrations that would have an impact on the actual consumption of dietary salt, that is, at suprathreshold concentrations. As pointed out by Contreras [60], in general, people do not add salt to food in order to be able to just detect it, but do so to a preferred suprathreshold level. It is noteworthy that amiloride tends to reduce suprathreshold intensities of perceived $\mathrm{NaCl}$ in adult volunteers [15]. However, a significant difference in taste intensity ratings between individuals with SNPs was found only for large concentrations of $\mathrm{NaCl}$, such as $1 \mathrm{M}$ [57]. Aqueous solutions of salt above $\sim 150 \mathrm{mM}$ are not preferred by humans [61]. In animals, salt levels exceeding tonicity of blood plasma are normally not accepted [62]. High salt concentrations activate other sensory pathways in addition to the ENaC-mediated one, including an amiloride-insensitive taste pathway and trigeminal nerve endings [5,22]. These components of salt reception mediate aversion responses and work as warning mechanisms to avoid the ingestion of hyperosmotic salt solutions $[5,10,63]$. Thus, the findings on SNPs of the ENaC $\beta$-subunit seemingly do not fit the model involving ENaC as low-salt receptor.

\section{Salt Taste Enhancers}

Chemicals able to increase the sensation evoked by $\mathrm{NaCl}$ without being salty themselves, the so-called "salt taste enhancers", have attracted the attention of researchers for many years [64]. The reason is that these substances may be used to reduce salt content in processed foods to prevent excessive sodium intake, which is linked to the development of hypertension and subsequent pathologies $[65,66]$. Research on the mechanisms underlying the action of salt taste enhancers has provided some clues on the peripheral events leading to salt taste perception in humans.

Studies on human $\alpha \beta \gamma$ - or $\delta \beta \gamma$-ENaC functionally expressed in Xenopus oocytes have shown that sodium current through $\mathrm{ENaCs}$ is activated by salt-taste-modulating substances, such as L-arginine (Arg) [48]. By monitoring the changes of intracellular calcium levels in cultured human fungiform taste (HBO) cells, $\mathrm{Xu}$ et al. [67] found recently that some arginyl dipeptides, which proved to work as potent salty taste enhancers (up to $20 \%$ increase in perceived saltiness [68]), induced a significant increase in the number of cultured cells responding to $\mathrm{NaCl}$. They also found that the effect required the presence of either $\alpha-\mathrm{ENaC}$ or $\delta-\mathrm{ENaC}$. These results clearly indicate that salt taste enhancers target the human sodium receptor $\mathrm{ENaC}$ in both the $\alpha \beta \gamma$ or $\delta \beta \gamma$ form. Unexpectedly, Arg was unable to stimulate cultured human taste cells [67], although it enhances the perceived saltiness in human sensory evaluations [48,68].

There are some aspects of the above studies that require keen consideration. In particular, it is remarkable how the effect of Arg may be affected by the cell system used to express human $\alpha \beta \gamma$ - or $\delta \beta \gamma$-ENaC. In Xenopus oocytes, Arg increases the sodium current through ENaCs [48], whereas in HBO cells, it is ineffective in changing intracellular calcium levels [67]. It is possible that this discrepancy may derive from the different experimental and methodological approach adopted. However, the finding that Arg potentiates ion currents through $\mathrm{ENaC}$ is, by itself, quite surprising. Both Arg and amiloride 
bear a guanidinium group (Figure 1), which occurs as a cation in physiological conditions (pH 7.4). It is believed that the positive charge-bearing guanidinium group of amiloride penetrates part of the $\mathrm{ENaC}$ channel pore, causing channel blockage, whereas the pyrazine group interacts with the outer mouth of the channel [69]. The chemical similarity may suggest that Arg, like amiloride, could affect $\mathrm{ENaC}$ directly from the extracellular space. Indeed, Ogawa et al. [70] suggested that "the guanidinium group of Arg may interact with sodium channels in taste bud membranes". Yet, Arg enhances the current through $\mathrm{ENaC}$, whereas amiloride reduces it.<smiles>N=C(N)NCCCC(N)C(=O)O</smiles><smiles>NC(N)=NC(=O)c1nc(Cl)c(N)nc1N</smiles>

Figure 1. Structure of L-arginine (top) and amiloride (bottom). Both chemicals bear a guanidinium group (red), which is protonated in physiological conditions. This group is believed to interact with the $\mathrm{ENaC}$ channel pore from the extracellular space.

\section{Salivary Proteins}

Proteins represent an important component of the saliva [71], the medium carrying $\mathrm{Na}^{+}$to the apical, chemosensitive tips of taste cells. Recent studies on human subjects have found a correlation between salivary serine-type endoprotease activity and sensitivity to $\mathrm{NaCl}$ [72]. Since serine proteases increase the activity of $\mathrm{ENaC}$ through proteolytic cleavage [73,74], the authors have proposed that endoproteases of the saliva might affect salt taste sensitivity by modifying ENaC functioning. Stolle et al. [75] have identified a tetrapeptide that is likely released from salivary proteins by serine-type endoprotease activity and that is able to enhance salt taste perception. This means that in the saliva of salt sensitive subjects, an endogenous salt enhancer might be produced by enzymatic cleavage. It was also found that the abundance of two salivary proteins, lipocalin- 1 and lysozyme $C$, could be related to individuals' low sensitivity to $\mathrm{NaCl}$. The authors have put forward the hypothesis that electrostatic interaction of these proteins with $\mathrm{ENaC}$ in taste cells may reduce the accessibility of sodium ions to ENaC [75]. These findings are clearly fascinating, but do not prove that ENaC actually functions as a sodium receptor in humans.

\section{Discussion}

The possible involvement of the ion channel, $\mathrm{ENaC}$, in human taste reception has been investigated with different approaches. To date, however, it is not possible to provide a definitive answer as to the role of the ENaC pathway in producing salty sensations due to inconsistent findings. Perhaps the more conflicting results are from psychophysical studies involving the use of amiloride, a pharmacological probe for $\mathrm{ENaC}$, to challenge saltiness perception. There are several issues regarding the adopted methodology that might be responsible for the observed discrepancies. For instance, the amiloride concentration used in sensory tests is not always adequate to avoid side effects on other ion channels and transporters. Thus, the apparent effect of amiloride in some studies (e.g., [12-14]) might be somehow misleading. Nonetheless, electrophysiological studies suggest that the application of salt solution on the human tongue induces a voltage drop across the mucosa that is similar to the one observed in laboratory animals. However, ENaC mRNAs are found also in nontaste epithelium $[44,48,76]$, raising the possibility that the ion current crossing the mucosa could also be due to $\mathrm{Na}^{+}$diffusion through epithelial cells. 
According to the model proposed for rodents, $\mathrm{ENaC}$ should be found at the apical membrane of taste cells, which stick out into the taste pore bathed by saliva containing taste stimuli $[3,8]$. Available data suggest that only the $\delta$-subunit localizes to the taste pore region in human taste buds, whereas other $\mathrm{ENaC}$ subunits seem to be segregated in the basolateral compartment, beneath the apical tips of taste cells. It is not yet known whether all the subunits are required to form a functional sodium receptor [41]. Differential expression of ENaC-subunits has been described in transporting epithelia [77], suggesting that endogenous channel in vivo may require only one or two subunits to work properly. $\delta$-ENaC expressed alone in Xenopus oocytes is able to mediate a membrane current [50]. Thus, the occurrence of the $\delta$-subunit in the taste pore region of human taste buds seems to suggest that it may function as a sodium receptor. Unfortunately, the microscopic analysis has not allowed establishing with confidence whether this subunit lies in the apical end of taste cells or in the tight junctions connecting adjacent taste cells just below the taste pore [48]. Indirect evidence supporting a role for $\mathrm{ENaC}$ in human salt taste has been provided by genetic studies [57] and by in vitro assays on cells expressing the human $\alpha \beta \gamma$ - or $\delta \beta \gamma$-ENaC $[48,67]$, although there is some inconsistency among these data. Recent analysis of the correlation between the salivary proteome and the salt sensitivity in human volunteers are seemingly consistent with a role of $\mathrm{ENaC}[72,75]$.

In conclusion, the available data are suggestive of possible involvement of $\mathrm{ENaC}$ in human sodium detection, although it is not clear whether this occurs at the beginning of the reception process (interaction between sodium receptor and $\mathrm{Na}^{+}$at the apical membrane of taste cells) or later on, after $\mathrm{Na}^{+}$ has been detected. The lack of the amiloride effect in some psychophysical studies $[16-18,20,21]$ and the presence of $\alpha-, \beta$-, and $\gamma$-subunit only in the basolateral portion of taste buds [48] seem to favor a role for $\mathrm{ENaC}$ downstream of the initial receptive events. Consistent with this hypothesis is the finding that SNPs in the gene coding for the $\mathrm{ENaC} \beta$-subunit affect suprathreshold sensitivity to salt solutions, that is, at concentration levels above the detection/recognition threshold [57]. Clearly, further research is required to obtain a coherent and thorough comprehension of the early events of sodium detection in human taste cells. This information represents the premise for understanding interindividual variability in the function of sodium taste receptors and its potential implications for eating behavior.

Funding: This research received no external funding.

Acknowledgments: This work was supported in part by Università di Modena e Reggio Emilia (FAR Dipartimentale 2018, 2019).

Conflicts of Interest: The author declares no conflict of interest.

\section{References}

1. Schiffman, S.S.; Erickson, R.P. A psychophysical model for gustatory quality. Physiol. Behav. 1971, 7, 617-633. [CrossRef]

2. Mattes, R.D. The taste for salt in humans. Am. J. Clin. Nutr. 1997, 65, 692S-697S. [CrossRef]

3. Lindemann, B. Taste reception. Physiol. Rev. 1996, 76, 718-766. [CrossRef]

4. McCaughey, S.A.; Scott, T.R. The taste of sodium. Neurosci. Biobehav. Rev. 1998, 22, 663-676. [CrossRef]

5. Bigiani, A. Salt taste. In The Senses. Olfaction and Taste, 2nd ed.; Meyerhof, W., Ed.; Elsevier: Amsterdam, The Netherlands, 2020; Volume III, in press. [CrossRef]

6. Breslin, P.A.; Huang, L. Human taste: Peripheral anatomy, taste transduction, and coding. Adv. Otorhinolaryngol. 2006, 63, 152-190. [CrossRef]

7. Witt, M. Anatomy and development of the human taste system. In Handbook of Clinical Neurology. Smell and Taste; Doty, R.L., Ed.; Elsevier: Amsterdam, The Netherlands, 2019; Volume 164, pp. 147-171.

8. Bigiani, A. Electrophysiology of sodium receptors in taste cells. J. Biomed. Sci. Eng. 2016, 9, $367-383$. [CrossRef]

9. Heck, G.L.; Mierson, S.; DeSimone, J.A. Salt taste transduction occurs through an amiloride-sensitivesodium transport pathway. Science 1984, 223, 403-405. [CrossRef]

10. Chandrashekar, J.; Kuhn, C.; Oka, Y.; Yarmolinsky, D.A.; Hummler, E.; Ryba, N.J.P.; Zuker, C.S. The cells and peripheral representation of sodium taste in mice. Nature 2010, 464, 297-301. [CrossRef] 
11. Schiffman, S.S.; Lockhead, E.; Maes, F.W. Amiloride redcuces the taste intensity of $\mathrm{Na}^{+}$and $\mathrm{Li}^{+}$salts and sweeteners. Proc. Natl. Acad. Sci. USA 1983, 80, 6136-6140. [CrossRef]

12. Tennissen, A.M. Amiloride reduces intensity responses of human fungiform papillae. Physiol. Behav. 1992, 51, 1061-1068. [CrossRef]

13. McCutcheon, N.B. Human psychophysical studies of saltiness suppression by amiloride. Physiol. Behav. 1992, 51, 1069-1074. [CrossRef]

14. Tennissen, A.M.; McCutcheon, N.B. Anterior tongue stimulation with amiloride suppress NaCl saltiness, but not citric acid sourness in humans. Chem. Senses 1996, 21, 113-120. [CrossRef]

15. Anand, K.K.; Zuniga, J.R. Effect of amiloride on suprathreshold $\mathrm{NaCl}, \mathrm{LiCl}$, and $\mathrm{KCl}$ salt taste in humans. Physiol. Behav. 1997, 62, 925-929. [CrossRef]

16. Desor, J.A.; Finn, J. Effects of amiloride on salt taste in humans. Chem. Senses 1989, 14, 793-803. [CrossRef]

17. Ossebaard, C.A.; Smith, D.V. Effect of amiloride on the taste of $\mathrm{NaCl}, \mathrm{Na}$-gluconate and $\mathrm{KCl}$ in humans: Implications for $\mathrm{Na}^{+}$receptor mechanisms. Chem. Senses 1995, 20, 37-46. [CrossRef]

18. Smith, D.V.; Ossebaard, C.A. Amiloride suppression of the taste intensity of sodium chloride: Evidence from direct magnitude scaling. Physiol. Behav. 1995, 4, 773-777. [CrossRef]

19. Ossebaard, C.A.; Smith, D.V. Amiloride suppresses the sourness of $\mathrm{NaCl}$ and LiCl. Physiol. Behav. 1996, 60, 1317-1322. [CrossRef]

20. Ossebaard, C.A.; Polet, I.A.; Smith, D.V. Amiloride effects on taste quality: Comparison of single and multiple response category procedures. Chem. Senses 1997, 22, 267-275. [CrossRef]

21. Halpern, B.P.; Darlington, R.B. Effects of amiloride on gustatory quality descriptions and temporal patterns produced by $\mathrm{NaCl}$. Chem. Senses 1998, 23, 501-511. [CrossRef]

22. Simon, S.A.; de Araujo, I.E.; Stapleton, J.R.; Nicolelis, M.A. Multisensory processing of gustatory stimuli. Chemosens. Percept. 2008, 1, 95-102. [CrossRef]

23. Kleyman, T.R.; Cragoe, E.J., Jr. Amiloride and its analogs as tools in the study of ion transport. J. Membr. Biol. 1988, 105, 1-21. [CrossRef] [PubMed]

24. Tang, C.-M.; Presser, F.; Morad, M. Amiloride selectively blocks the low threshold (T) calcium channel. Science 1988, 240, 213-215. [CrossRef] [PubMed]

25. Béhé, P.; DeSimone, J.A.; Avenet, P.; Lindemann, B. Membrane currents in taste cells of the rat fungiform papilla. J. Gen. Physiol. 1990, 96, 1061-1084. [CrossRef] [PubMed]

26. Bigiani, A.; Cuoghi, V. Localization of amiloride-sensitive sodium current and voltage-gated calcium currents in rat fungiform taste cells. J. Neurophysiol. 2007, 98, 2483-2487. [CrossRef]

27. Kinsella, J.L.; Aronson, P.S. Amiloride inhibition of the $\mathrm{Na}^{+}-\mathrm{H}^{+}$exchanger in renal microvillus membrane vesicles. Am. J. Physiol. 1981, 241, F374-F379. [CrossRef]

28. Lundy, R.F., Jr.; Pittman, D.W.; Contreras, R.J. Role for epithelial $\mathrm{Na}^{+}$channels and putative $\mathrm{Na}^{+} / \mathrm{H}^{+}$ exchangers in salt taste transduction in rats. Am. J. Physiol. 1997, 273, R1923-R1931. [CrossRef]

29. Vinnikova, A.K.; Alam, R.I.; Malik, S.A.; Ereso, G.L.; Feldman, G.M.; McCarty, J.M.; Knepper, M.A.; Heck, G.L.; DeSimone, J.A.; Lyall, V. Na ${ }^{+}-\mathrm{H}^{+}$exchange activity in taste receptor cells. J. Neurophysiol. 2004, 91, 1297-1313. [CrossRef] [PubMed]

30. Lyall, V.; Alam, R.I.; Malik, S.A.; Phan, T.H.; Vinnikova, A.K.; Heck, G.L.; DeSimone, J.A. Basolateral Na ${ }^{+}-\mathrm{H}^{+}$ exchanger-1 in rat taste receptor cells is involved in neural adaptation to acidic stimuli. J. Physiol. 2004, 556, 159-173. [CrossRef]

31. Kuijpers, G.A.; De Pont, J.J.; Van Nooy, I.G.; Fleuren-Jakobs, A.M.; Bonting, S.L.; Rodrigues de Miranda, J.F. Amiloride is a cholinergic antagonist in the rabbit pancreas. Biochim. Biophys. Acta 1984, 804, 237-244. [CrossRef]

32. Ogura, T. Acetylcholine increases intracellular $\mathrm{Ca}^{2+}$ in taste cells via activation of muscarinic receptors. J. Neurophysiol. 2002, 87, 2643-2649. [CrossRef]

33. Eguchi, K.; Ohtubo, Y.; Yoshii, K. Functional expression of M3, a muscarinic acetylcholine receptor subtype, in taste bud cells of mouse fungiform papillae. Chem. Senses 2008, 33, 47-55. [CrossRef] [PubMed]

34. DeSimone, J.A.; Heck, G.L.; DeSimone, S.K. Active ion transport in dog tissue: A possible role in taste. Science 1981, 214, 1039-1041. [CrossRef] [PubMed]

35. DeSimone, J.A.; Heck, G.L.; Mierson, S.; DeSimone, S.K. The active ion transport properties of canine lingual epithelia in vitro. Implications forgustatory transduction. J. Gen. Physiol. 1984, 83, 633-656. [CrossRef] 
36. Feldman, G.M.; Mogyorósi, A.; Heck, G.L.; DeSimone, J.A.; Santos, C.R.; Clary, R.A.; Lyall, V. Salt-evoked lingual surface potential in humans. J. Neurophysiol. 2003, 90, 2060-2064. [CrossRef] [PubMed]

37. Feldman, G.M.; Heck, G.L.; Smith, N.L. Human salt taste and the lingual surface potential correlate. Chem. Senses 2009, 34, 373-382. [CrossRef] [PubMed]

38. Benos, D.J.; Stanton, B.A. Functional domains within the degenerin/epithelial sodium channel (Deg/ENaC) superfamily of ion channels. J. Physiol. 1999, 520, 631-644. [CrossRef] [PubMed]

39. Kellenberger, S.; Schild, L. International Union of Basic and Clinical Pharmacology. XCI. structure, function, and pharmacology of acid-sensing ion channels and the epithelial $\mathrm{Na}^{+}$channel. Pharmacol. Rev. 2015, 67, 1-35. [CrossRef]

40. Canessa, C.M.; Schild, L.; Buell, G.; Thorens, B.; Gautschi, I.; Horisberger, J.D.; Rossier, B.C. Amiloride-sensitive epithelial $\mathrm{Na}^{+}$channel is made of three homologous subunits. Nature 1994, 367, 463-467. [CrossRef]

41. Lossow, K.; Hermans-Borgmeyer, I.; Meyerhof, W.; Behrens, M. Segregated expression of ENaC subunits in taste cells. Chem. Senses 2020, in press. [CrossRef]

42. Simon, S.A.; Holland, V.F.; Benos, D.J.; Zampighi, G.A. Transcellular and paracellular pathways in lingual epithelia and their influence in taste transduction. Microsc. Res. Tech. 1993, 26, 196-208. [CrossRef]

43. Kretz, O.; Barbry, P.; Bock, R.; Lindemann, B. Differential expression of RNA and protein of the three pore-forming subunits of the amiloride-sensitive epithelial sodium channel in taste buds of the rat. J. Histochem. Cytochem. 1999, 47, 51-64. [CrossRef] [PubMed]

44. Lin, W.; Finger, T.E.; Rossier, B.C.; Kinnamon, S.C. Epithelial $\mathrm{Na}^{+}$channel subunits in rat taste cells: Localization and regulation by aldosterone. J. Comp. Neurol. 1999, 405, 406-420. [CrossRef]

45. Shigemura, N.; Islam, A.A.; Sadamitsu, C.; Yoshida, R.; Yasumatsu, K.; Ninomiya, Y. Expression of amiloride-sensitive epithelial sodium channels in mouse taste cells after chorda tympani nerve crush. Chem. Senses 2005, 30, 531-538. [CrossRef] [PubMed]

46. Yoshida, R.; Horio, N.; Murata, Y.; Yasumatsu, K.; Shigemura, N.; Ninomiya, Y. NaCl responsive taste cells in the mouse fungiform taste buds. Neuroscience 2009, 159, 795-803. [CrossRef]

47. Rossier, O.; Cao, J.; Huque, T.; Spielman, A.I.; Feldman, R.S.; Medrano, J.F.; Brand, J.G.; le Coutre, J. Analysis of a human fungiform papillae cDNA library and identification of taste-related genes. Chem. Senses 2004, 29, 13-23. [CrossRef]

48. Stähler, F.; Riedel, K.; Demgensky, S.; Neumann, K.; Dunkel, A.; Täubert, A.; Raab, B.; Behrens, M.; Raguse, J.-D.; Hofmann, T.; et al. A role of the epithelial sodium channel in human salt taste transduction? Chemosens. Percept. 2008, 1, 78-90. [CrossRef]

49. Huque, T.; Cowart, B.J.; Dankulich-Nagrudny, L.; Pribitkin, E.A.; Bayley, D.L.; Spielman, A.I.; Feldman, R.S.; Mackler, S.A.; Brand, J.G. Sour ageusia in two individuals implicates ion channels of the ASIC and PKD families in human sour taste perception at the anterior tongue. PLoS ONE 2009, 4, e7347. [CrossRef]

50. Waldmann, R.; Champigny, G.; Bassilana, F.; Voilley, N.; Lazdunski, M. Molecular cloning and functional expression of a novel amiloride-sensitive $\mathrm{Na}^{+}$channel. J. Biol. Chem. 1995, 270, 27411-27414. [CrossRef]

51. Ji, H.-L.; LaToya, R.; Bishop, L.R.; Anderson, S.J.; Catherine, M.; Fuller, C.M.; Benos, D.J. The role of Pre-H2 domains of $\alpha$ - and $\delta$-epithelial $\mathrm{Na}^{+}$channels in ion permeation, conductance, and amiloride sensitivity. J. Biol. Chem. 2004, 279, 8428-8440. [CrossRef]

52. Ji, H.-L.; Su, X.-F.; Kedar, S.; Li, J.; Barbry, P.; Smith, P.R.; Matalon, S.; Benos, D.J. $\delta$-subunit confers novel biophysical features to $\alpha \beta \gamma$-human epithelial sodium channel (ENaC) via a physical interaction. J. Biol. Chem. 2006, 281, 8233-8241. [CrossRef]

53. Bachmanov, A.A.; Bosak, N.P.; Lin, C.; Matsumoto, I.; Ohmoto, M.; Reed, D.R.; Nelson, T.M. Genetics of taste receptors. Curr. Pharmaceut. Des. 2014, 20, 2669-2683. [CrossRef] [PubMed]

54. Petrik, D.; Myoga, M.H.; Grade, S.; Gerkau, N.J.; Pusch, M.; Rose, C.R.; Grothe, B.; Götz, M. Epithelial sodium channel regulates adult neural stem cell proliferation in a flow-dependent manner. Cell Stem Cell 2018, 22, 865-878. [CrossRef] [PubMed]

55. Feng, P.; Huang, L.; Wang, H. Taste bud homeostasis in health, disease, and aging. Chem. Senses 2014, 39, 3-16. [CrossRef] [PubMed]

56. Barlow, L.A. Progress and renewal in gustation: New insights into taste bud development. Development 2015, 142, 3620-3629. [CrossRef] [PubMed] 
57. Dias, A.G.; Rousseau, D.; Duizer, L.; Cockburn, M.; Chiu, W.; Nielsen, D.; El-Sohemy, A. Genetic variation in putative salt taste receptors and salt taste perception in humans. Chem. Senses 2013, 38, 137-145. [CrossRef] [PubMed]

58. Firsov, D.; Schild, L.; Gautschi, I.; Mérillat, A.M.; Schneeberger, E.; Rossier, B.C. Cell surface expression of the epithelial Na channel and a mutant causing Liddle syndrome: A quantitative approach. Proc. Natl. Acad. Sci. USA 1996, 93, 15370-15375. [CrossRef] [PubMed]

59. Konstas, A.A.; Korbmacher, C. The $\gamma$-subunit of ENaC is more important for channel surface expression than the $\beta$-subunit. Am. J. Physiol. Cell Physiol. 2003, 284, C447-C456. [CrossRef]

60. Contreras, A.C. Salt taste and disease. Am. J. Clin. Nutr. 1978, 31, 1088-1097. [CrossRef]

61. Beauchamp, G.K. The human preference for excess salt. Am. Sci. 1987, 75, 27-33.

62. Duncan, C.J. Salt preference of birds and mammals. Physiol. Zool. 1962, 35, 120-132. [CrossRef]

63. Oka, Y.; Butnaru, M.; von Buchholtz, L.; Ryba, N.J.; Zuker, C.S. High salt recruits aversive taste pathways. Nature 2013, 494, 472-475. [CrossRef] [PubMed]

64. Dötsch, M.; Busch, J.; Batenburg, M.; Liem, G.; Tareilus, E.; Mueller, R.; Meijer, G. Strategies to reduce sodium consumption: A food industry perspective. Crit. Rev. Food Sci. Nutr. 2009, 49, 841-851. [CrossRef] [PubMed]

65. Burnier, M.; Wuerzner, G.; Bochud, M. Salt, blood pressure and cardiovascular risk: What is the most adequate preventive strategy? A Swiss perspective. Front. Physiol. 2015, 6, 227. [CrossRef] [PubMed]

66. Mozaffarian, D.; Fahimi, S.; Singh, G.M.; Micha, R.; Khatibzadeh, S.; Engell, R.E.; Lim, S.; Danaei, G.; Ezzati, M.; Powles, J. Global Burden of Diseases Nutrition and Chronic Diseases Expert Group. Global sodium consumption and death from cardiovascular causes. N. Engl. J. Med. 2014, 371, 624-634. [CrossRef] [PubMed]

67. Xu, J.J.; Elkaddi, N.; Garcia-Blanco, A.; Spielman, A.I.; Bachmanov, A.A.; Chung, H.Y.; Ozdener, M.H. Arginyl dipeptides increase the frequency of $\mathrm{NaCl}$-elicited responses via epithelial sodium channel alpha and delta subunits in cultured human fungiform taste papillae cells. Sci. Rep. 2017, 7, 7483. [CrossRef]

68. Schindler, A.; Dunkel, A.; Stähler, F.; Backes, M.; Ley, J.; Meyerhof, W.; Hofmann, T. Discovery of salt taste enhancing arginyl dipeptides in protein digests and fermented fish sauces by means of a sensomics approach. J. Agric. Food Chem. 2011, 59, 12578-12588. [CrossRef]

69. Kellenberger, S.; Schild, L. Epithelial sodium channel/degenerin family of ion channels: A variety of functions for a shared structure. Physiol. Rev. 2002, 82, 735-767. [CrossRef]

70. Ogawa, T.; Nakamura, T.; Tsuji, E.; Miyanaga, Y.; Nakagawa, H.; Hirabayashi, H.; Uchida, T. The combination effect of L-arginine and $\mathrm{NaCl}$ on bitterness suppression of amino acid solutions. Chem. Pharm. Bull. 2004, 52, 172-177. [CrossRef]

71. Carpenter, G.H. The secretion, components, and properties of saliva. Annu. Rev. Food Sci. Technol. 2013, 4, 267-276. [CrossRef]

72. Stolle, T.; Grondinger, F.; Dunkel, A.; Meng, C.; Médard, G.; Kuster, B.; Hofmann, T. Salivary proteome patterns affecting human salt taste sensitivity. J. Agric. Food Chem. 2017, 65, 9275-9286. [CrossRef]

73. Hughey, R.P.; Carattino, M.D.; Kleyman, T.R. Role of proteolysis in the activation of epithelial sodium channels. Curr. Opin. Nephrol. Hypertens. 2007, 16, 444-450. [CrossRef] [PubMed]

74. Kleyman, T.R.; Carattino, M.D.; Hughey, R.P. ENaC at the cutting edge: Regulation of epithelial sodium channels by proteases. J. Biol. Chem. 2009, 284, 20447-20451. [CrossRef] [PubMed]

75. Stolle, T.; Grondinger, F.; Dunkel, A.; Hofmann, T. Quantitative proteomics and SWATH-MS to elucidate peri-receptor mechanisms in human salt taste sensitivity. Food Chem. 2018, 254, 95-102. [CrossRef] [PubMed]

76. Li, X.-J.; Blackshaw, S.; Snyder, S.H. Expression and localization of amiloride-sensitive sodium channel indicate a role for non-taste cells in taste perception. Proc. Natl. Acad. Sci. USA 1994, 91, 1814-1818. [CrossRef]

77. Weisz, O.A.; Johnson, J.P. Noncoordinate regulation of ENaC: Paradigm lost? Am. J. Physiol. Ren. Physiol. 2002, 285, F833-F842. [CrossRef]

(C) 2020 by the author. Licensee MDPI, Basel, Switzerland. This article is an open access article distributed under the terms and conditions of the Creative Commons Attribution (CC BY) license (http://creativecommons.org/licenses/by/4.0/). 